\title{
Consumer Perceptions and Behaviour toward Credit Usage in Kenya
}

\author{
Davis Bundi Ntwiga*, Arthur Wafula Wanyonyi \\ School of Mathematics, University of Nairobi, Nairobi, Kenya \\ Email: *dbundi@uonbi.ac.ke
}

How to cite this paper: Ntwiga, D.B. and Wanyonyi, A.W. (2020) Consumer Perceptions and Behaviour toward Credit Usage in Kenya. Open Access Library Journal, 7: e6204.

https://doi.org/10.4236/oalib.1106204

Received: March 3, 2020

Accepted: May 31, 2020

Published: June 3, 2020

Copyright $\odot 2020$ by author(s) and Open Access Library Inc.

This work is licensed under the Creative Commons Attribution International License (CC BY 4.0).

http://creativecommons.org/licenses/by/4.0/

(c) (i) Open Access

\begin{abstract}
Consumer behaviour and perceptions evolve over time and affect credit usage from the financial service providers. We use the 2016 FinAccess Household survey data of 2015 from 8665 households to examine how perceptions and behaviour of un(der) banked consumers can shape their dynamics towards credit usage. The perceptions and behaviour are based on source of financial advice, trust of the institutions, characteristics of the financial instrument and cost of credit. The multinomial logistic regression model predicts the odds of credit usage based on perceptions and behaviour of the consumers. The categories for the credit usage are: have credit, used to have credit and never had credit. Consumer perceptions and behaviour based on cost of credit and trust increase credit usage, while source of financial advice had minimal influence on credit usage. The characteristics of the financial instrument are catering to emergencies and being safe to use increased credit usage. The Savings and Credit Cooperative Organizations and microfinance are the most trusted financial institutions by the consumers, while shylock has the highest cost of credit. Radio as a source of financial advice reduced credit usage. The dynamics of credit usage are shaped by the perceptions and behaviour of the consumers.
\end{abstract}

\section{Subject Areas}

Credit Risk, Behaviourial Finance, Financial Services

\section{Keywords}

Credit Usage, Perceptions, Behaviour, Cost of Credit, Trust, Source of Advice, Financial Instrument

\section{Introduction}

Financial inclusion is defined as the use of formal accounts and is critical in re- 
ducing poverty and increasing inclusive economic growth [1]. When individuals participate in the financial system, they can invest in education, manage risk, start and expand businesses, absorb financial shocks, increase savings and boost productive investments [2]. Financial inclusion increases with lower account costs, stronger legal rights, more politically stable environments and the proximity to financial service providers [1] [3]. The number of adults globally who have opened an account at a financial institution has increased with $51 \%$ having an account in 2011, 62\% in 2014, and 69\% in 2017 [4].

Globally, around 1.7 billion are unbanked, 56\% of the unbanked are women and $50 \%$ of the unbanked are from $40 \%$ of the poorest households [4], while $73 \%$ of the 1.7 billion reside in 25 countries, mostly in Asia and Africa [5]. A comparison of the gender shows that $72 \%$ of the men have an account compared with $65 \%$ of the women, which has remained unchanged since 2011 [4]. The two major forms of financial exclusion are voluntary and involuntary exclusion. For voluntary exclusion, the consumer may not be in need of the services or restrictions due to culture or religion. For the involuntary exclusion, the reasons could be due to insufficient income, high risk, discrimination, weak contract enforcement, lack of information, product features or price barriers [3].

Financial institutions are traditionally been in the forefront to foster financial inclusion. The efficiency of banking institutions fosters economic development, facilitates financial intermediation and contributes to optimal allocation of financial resources [6]. There has been an impressive growth in financial inclusion in SSA in recent years driven by growth in agent banking and mobile money where $43 \%$ of adults are financially included. The estimated global financial opportunity from the un(der) banked customers is USD 380 billion in annual revenues [7].

There is growing consumer demand where access and usage are influenced by the perceptions and behaviour of the consumer due to the perceived risks, technological failure and lack of consumer protection [1]. The financial opportunity around the globe among the un(der) banked is approximately USD 380 billion in annual revenues. In SSA, 95 million adults who are un(der) banked receive cash payment and 65 million use semi-formal savings [7] with 57\% financially excluded [7] and banks penetration being below 35\% [5]. In the midst of these developments, [8] observes that trust plays a central role in financial decision making process where a correlation is observed between financial trust and credit usage. Trust is related to attitudes, knowledge, preferences and behaviour with financial trust being key factor in financial literacy and risk tolerance [8]. Negative perception inhibits the use of financial services and the remedy would be to develop health curative measures to diagnose borrower personal experiences, cost and benefits of using the product or services [9]. As consumers are faced with information asymmetry, having multiple sources of information can alter their perceptions and credit usage [9]. The level of financial knowledge affects risk perception as high levels of product knowledge lowers indecision and 
even financially literate individuals exhibit behaviorial biases in financial products and services [10].

Tapping into evolving consumer behaviour, perceptions, access and trust will drive sustainable credit usage where $57 \%$ of adults in SSA are financially excluded [7]. The banks penetration in SSA is below $35 \%$ and approximately $80 \%$ of Africa's one billion population lack access to formal bank services [5]. Trust is crucial for the industry growth as the public has an adverse view of the financial systems. This study delves on the perceptions and behaviour of the consumers, and how they affect credit usage from the financial service providers and shape the dynamics of credit usage. The variables to unearth perceptions and behaviour are source of financial advice, trust, cost of credit and characteristics exhibited by the financial instruments.

The rest of the paper is organized as follows. Section 2 presents the literature review. Section 3 has the methodology, data analysis methods and the multinomial logistic regression model. In section 4 , we have the analysis, discussions and findings of credit usage and consumer perceptions and behaviour; the odds to currently have to never had credit and used to have to never had credit. Section 5 is the conclusion of the study and ideas for further research.

\section{Review}

The best indicators of financial access are the number of people, firms and households receiving credit and using other financial products from the financial service providers. Credit demand is difficult to size but there is huge demand for unsecured and short-term credit at the consumer level [11] as the ability to access micro-credit loan promotes individual outcomes [12].

The FinAccess Household Survey of 2016 noted that the main reasons people join a group are: access to a lump sum for emergencies, daily needs, social reasons, keep money safe, acquire a lump sum for investment and commitment to save [13]. This compares well to the financial diaries study in which it indicates the implications of the findings to the financial services providers as: they should provide products that cater to small and inconsistent incomes; offer better tools for managing day to day transactions and risks; assist women better leverage their social networks; accessibility; and services that endure and support women to face major life transitions [14] [15].

People may have access to financial services but do not use them. The relationship between access and usage is complex and there are a number of contributing factors. Such services may be; un-affordable, fear of rejection, unsuitable to their needs and the service provider being unwilling to service that market segment due to the poor credit risk profiles [16] [17]. A study by [4] noted the reasons why adults remain un(der)banked, where $20 \%$ cited lack of documentation and distrust of the financial service providers with $66 \%$ saying they have too little money to use an account. [18] findings in Mexico indicate an overwhelming majority being unbanked at $89 \%$ due to lack of enough money, $25 \%$ cited cost and distance and 
another $25 \%$ do not have an account as a family member already has one, only $6 \%$ cited religious reasons. Lower barriers are reported in countries with lower account costs and greater penetration of financial service providers [1].

Influences of risk perceptions are unpredictable outcomes, emotional reactions, uncertainty due to lack of knowledge and seriousness of the consequences. [19] noted that consumer behaviour observed over different products offers differing price sensitivity reactions and [20] noted that the influence is based on the type of financial product. The subjectivity of how risk is perceived creates uncertainties due to lack of knowledge and consequences therein [21]. A robust relationship between financial behaviour and perceptions on credit access exists [9] as trust forms the link in the relationship [20] [22]. Consumers are only rational to a certain extent, as perceptions and behaviour are shaped by the environment, how it is conceptualized since no universally agreed measurement exists [21]. A borrower's experiences, costs and benefits are important to change financial behaviour and engender financial inclusion [9].

A study by [8] noted that financial trust is highly correlated with different forms of financial advice-seeking but causality could not be determined. Financial perception on access and usage decreased as the depth of usage deepened from basic to advance levels of financial services and products [9]. Risk preferences and financial decisions are sensitive to the way financial information is disclosed [23]. A biased risk perception is based on financial knowledge, personal traits and investment habits [10]. Information disclosure must be simple and salient to allow for greater transparency in cost and time horizon for the decision-making process. The subjectivity of risk is observed as risk may mean different things to different people depending on their risk dimension [10].

The Technology Acceptance Model (TAM) developed by Davis in 1989 has two constructs, the perceived ease of use and perceived usefulness of information technology [24]. Perceived usefulness highlights the degree to which an individual believes that using a particular technology would enhance their life performance. Perceived ease of use indicates the degree to which a person believes that using technology would be free of effort [25]. The TAM is the most appropriate as compared to Theory of Planned Behaviour and Theory of Reasoned Action when applied in online contexts. TAM is ideal for information system usage based on concepts of ease of use and is more robust to cater for usage dynamics [25]. TAM focuses on perceptions, behaviour, convenience and usefulness of information technology to increase its adoption. The constant changes in technology create threats to existing and new business models [26]. This theory captures the study objective, the perceptions and behaviour of individuals towards credit usage influences the uptake of consumer credit and is affected by numerous factors from financial literacy to risk perception and attitude.

\section{Multinomial Logistic Regression Model}

The data source is the 2016 FinAccess Household Survey data which is both qua- 
litative and quantitative collected collaboratively by Central Bank of Kenya, Kenya National Bureau of Statistics and Financial Sector Deepening in 2015. A total of 8665 households were interviewed during the survey on access and usage of financial services in Kenya [13]. The analysis on this data is to understand the perceptions and behaviour of consumer based on cost of loans (interest rate), source of advice, trust of the financial provider and the main characteristics of a good financial instrument (see Table 2). This is to analyze the influence of these consumer perceptions and behaviour on credit usage. Multinomial logistic regression predicted the odds of credit usage based on the perceptions and behaviour of consumers.

In the multinomial regression, $C=3$ is the number of categories of the response variable (credit usage), $K$ is the number of categories in each explanatory variable and $N$ is the set of observations. The model is generalized as

$$
\log \left(\frac{\pi_{i}^{j}}{\pi^{0}}\right)=Y_{i}=\alpha^{(j)}+\beta_{i}^{(j)} X_{1 j}+\beta_{k}^{(j)} X_{k j}
$$

where $i=1,2, C-1$, with $C$ being the number of categories in the response variable. $k=1,2, K-1$, with $K$ being the number of categories in each explanatory variable. The $C-1$ and $K-1$ means that one of the categories is the reference category in the logit regression and $j=1,2, N$, being the number of explanatory variables in the model. $\alpha^{(j)}, \beta_{1}^{(j)}, \beta_{k}^{(j)}$ are unknown population parameters to be estimated in the logit regression model.

The observations $Y_{i}$ have a multinomial distribution with probability parameters: $\pi_{i}^{(0)}, \pi_{i}^{(1)}, \pi_{i}^{(C-1)}$, where $i=1,2, N$ and $C=3$. There are $X_{1}, X_{2}, X_{K}$ explanatory variables for each of the $N$ set of observations. The multicollinearity test (see Table 2 ) shows no presence of multicollinearity $(1<V I F<1.1)$. The correct classification of the three categories in the response variable is tabulated in Table 1.

Table 1 shows the predicted classification on the three categories of credit usage. The categories, $C=3$ are: currently have credit, used to have credit and never had credit, with the later as the reference category. The model correctly classifies $63.9 \%$ of the subjects in currently have credit with $7.8 \%$ of used to have credit and $57.2 \%$ of the never had credit being correctly classified. Overall, the success rate is $45.5 \%$ for the model to correctly classify the three categorical variables.

Table 1. Classification of the response variable categories.

\begin{tabular}{ccccc}
\hline \multirow{2}{*}{ Observed } & \multicolumn{4}{c}{ Predicted } \\
\cline { 2 - 5 } & Currently have & Used to have & Never had & Percent Correct (\%) \\
\hline Currently have & $4,693,516$ & 440,455 & $2,215,715$ & 63.9 \\
Used to have & $2,881,364$ & 435,624 & $2,291,733$ & 7.8 \\
Never had & $2,464,030$ & 354,886 & $3,771,507$ & 57.2 \\
Overall Percentage (\%) & 51.4 & 6.3 & 42.4 & 45.5 \\
\hline
\end{tabular}




\section{Credit Usage and Consumer Perceptions and Behaviour}

The multinomial logistic regression predicted the odds of the credit usage to the perceptions and behaviour of the consumers. The discussion is based on Figure 1, Table 2 and Table 3.

In Figure 1, the first plot (source of financial advice) shows that customers who seek for financial advice from self or family/friends were the majority in the sample and had an almost equal proportion of credit usage. In the second plot (characteristics of financial instruments), those customers who felt a financial instrument is easy to access had almost equal proportions among those who currently have, used to have and never had credit. An instrument that helps in emergencies was more favored by those who currently have credit. The third plot (most trusted financial provider) shows that those who currently have credit felt that banks were the most trusted, followed by mobile money with almost equal proportions in the three credit usage categories. In the fourth plot (highest interest rate), those who currently have credit felt that banks had the highest interest rates, while those who never had credit did not know which institution charged high interest rates.

Table 2 shows the categories of the response variable (three categories) and explanatory variables each with eight categories. The reference category is the last category for each variable. Codes in Figure 1 and Table 3 are presented in Table 2. The acronyms are: SACCO_Savings and Credit Cooperative Organizations; ROSCA-Rotating Savings and Credit Association; Chama-an informal cooperative society; KCB Mpesa-a financial technology company under the Kenya Commercial Bank; Mshwari-a Fintech under the partnership of Safaricom
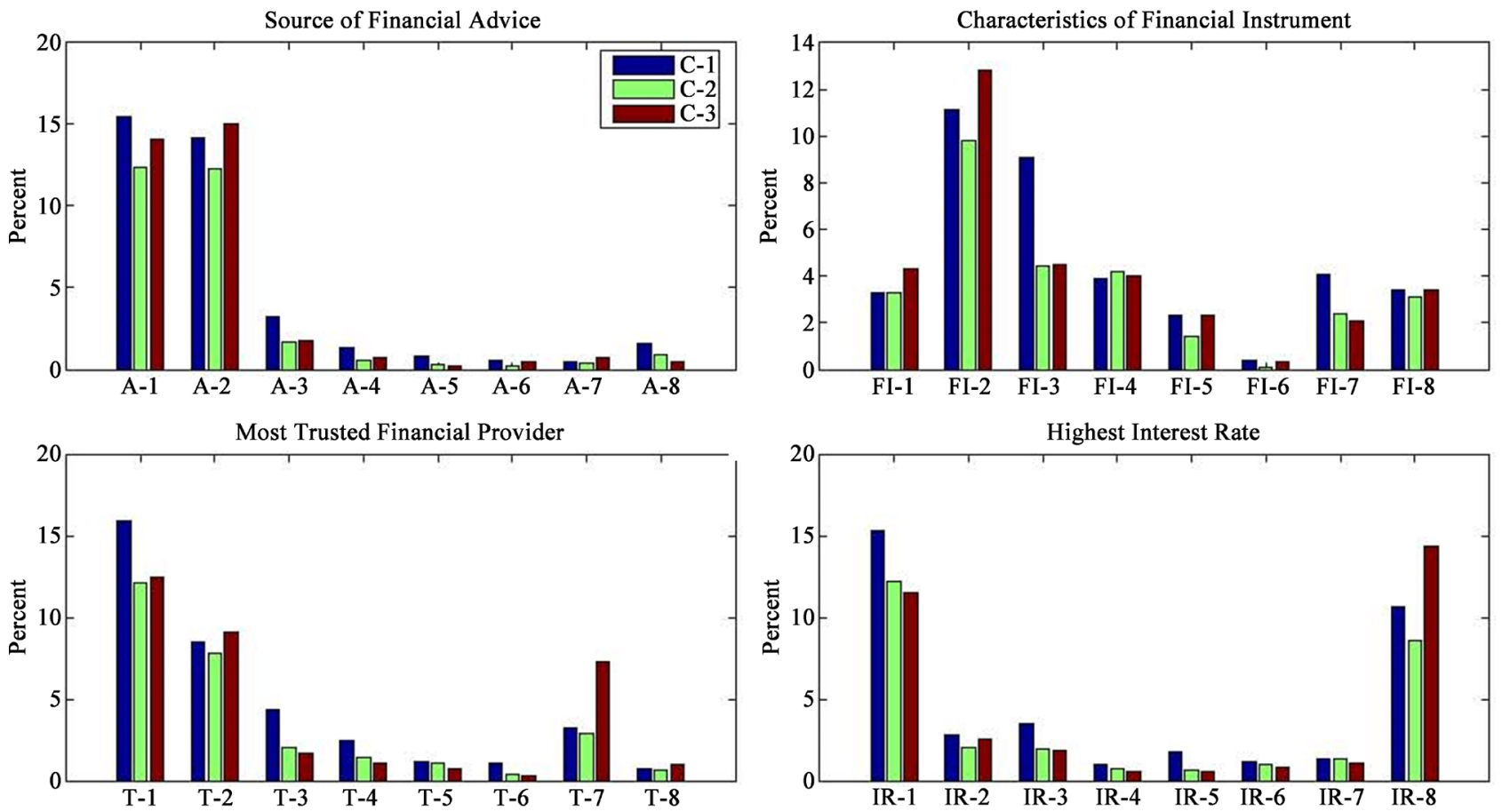

Figure 1. Credit usage against consumer perceptions and behaviour. 
Table 2. A summary of credit usage, perceptions and behaviour of consumers.

\begin{tabular}{|c|c|c|c|c|}
\hline Variable & Categories & Code & Percent & VIF \\
\hline \multirow[t]{3}{*}{ Credit Usage } & Currently have credit & $\mathrm{C}-1$ & 37.60 & \\
\hline & Used to have credit & $\mathrm{C}-2$ & 28.70 & \\
\hline & Never had credit & $\mathrm{C}-3$ & 33.70 & \\
\hline \multirow[t]{8}{*}{ Source of financial advice } & Self & A-1 & 42.00 & 1.011 \\
\hline & Friends/Family & A-2 & 41.50 & \\
\hline & Bank & A-3 & 6.70 & \\
\hline & ROSCA/Chama & A-4 & 2.50 & \\
\hline & SACCO & A-5 & 1.30 & \\
\hline & Don't Know & A-6 & 1.30 & \\
\hline & Radio & A-7 & 1.50 & \\
\hline & Others & A- 8 & 3.10 & \\
\hline \multirow{8}{*}{$\begin{array}{l}\text { Characteristics of } \\
\text { financial instrument }\end{array}$} & Keep most money & FI-1 & 10.90 & 1.00 \\
\hline & Easily accessed & FI-2 & 33.80 & \\
\hline & Helps in Emergencies & FI-3 & 18.00 & \\
\hline & Most trusted & FI-4 & 12.00 & \\
\hline & Use most often & FI-5 & 6.00 & \\
\hline & Money to invest & FI-6 & 0.80 & \\
\hline & Safest & FI-7 & 8.70 & \\
\hline & Others & FI-8 & 9.90 & \\
\hline \multirow[t]{8}{*}{ Most trusted } & Bank & $\mathrm{T}-1$ & 40.50 & 1.088 \\
\hline & Mobile Money & $\mathrm{T}-2$ & 25.40 & \\
\hline & SACCO & $\mathrm{T}-3$ & 8.20 & \\
\hline & ROSCA/Chama & $\mathrm{T}-4$ & 5.00 & \\
\hline & FinTech (Mshwari/KCB Mpesa) & $\mathrm{T}-5$ & 3.20 & \\
\hline & Microfinance & T-6 & 1.80 & \\
\hline & None & $\mathrm{T}-7$ & 13.50 & \\
\hline & Others & $\mathrm{T}-8$ & 2.60 & \\
\hline \multirow{8}{*}{$\begin{array}{l}\text { Provider with highest } \\
\text { interest rate }\end{array}$} & Bank & IR-1 & 39.00 & 1.099 \\
\hline & SACCO & IR-2 & 7.50 & \\
\hline & Microfinance & IR-3 & 7.30 & \\
\hline & Informal moneylender & IR-4 & 2.40 & \\
\hline & Shylock & IR-5 & 3.00 & \\
\hline & ROSCA/chama & IR-6 & 3.00 & \\
\hline & FinTech (Mshwari/KCB MPesa) & IR-7 & 3.90 & \\
\hline & Do not know & IR-8 & 33.70 & \\
\hline
\end{tabular}

VIF-Variance Inflation Factor (test for multicollinearity). 
Table 3. Parameter estimates for perceptions and behavior.

\begin{tabular}{|c|c|c|c|c|c|c|c|c|c|}
\hline \multirow{2}{*}{ Credit } & & & & & & & & \multicolumn{2}{|c|}{$95 \mathrm{CI}$ for $\operatorname{Exp}(\mathrm{B})$} \\
\hline & & & & & & & & Low & Upper \\
\hline Usage & Code & B & Std Error & Wald & $\mathrm{df}$ & Sig. & $\operatorname{Exp}(B)$ & Bound & Bound \\
\hline \multirow[t]{33}{*}{$\mathrm{C}-1$} & Intercept & -0.049 & 0.005 & 88.763 & 1 & 0.000 & & & \\
\hline & A-1 & -0.519 & 0.004 & $21,397.579$ & 1 & 0.000 & 0.595 & 0.591 & 0.599 \\
\hline & A-2 & -0.733 & 0.004 & $42,765.622$ & 1 & 0.000 & 0.481 & 0.477 & 0.484 \\
\hline & A-3 & -0.255 & 0.004 & 3964.079 & 1 & 0.000 & 0.775 & 0.768 & 0.781 \\
\hline & A- 4 & -0.406 & 0.005 & 6894.407 & 1 & 0.000 & 0.666 & 0.660 & 0.673 \\
\hline & A-5 & 0.322 & 0.007 & 2273.151 & 1 & 0.000 & 1.380 & 1.362 & 1.399 \\
\hline & A-6 & -0.264 & 0.006 & 2133.168 & 1 & 0.000 & 0.768 & 0.759 & 0.776 \\
\hline & A-7 & -1.099 & 0.006 & $38,440.638$ & 1 & 0.000 & 0.333 & 0.329 & 0.337 \\
\hline & A-8 & 0 & & & 0 & & & & \\
\hline & FI-1 & -0.233 & 0.002 & 8856.628 & 1 & 0.000 & 0.792 & 0.788 & 0.796 \\
\hline & FI-2 & -0.088 & 0.002 & 1862.271 & 1 & 0.000 & 0.916 & 0.912 & 0.920 \\
\hline & FI-3 & 0.776 & 0.002 & $119,415.028$ & 1 & 0.000 & 2.173 & 2.164 & 2.183 \\
\hline & FI-4 & -0.046 & 0.002 & 349.657 & 1 & 0.000 & 0.955 & 0.951 & 0.960 \\
\hline & FI-5 & 0.069 & 0.003 & 600.072 & 1 & 0.000 & 1.072 & 1.066 & 1.078 \\
\hline & FI-6 & 0.307 & 0.006 & 2670.406 & 1 & 0.000 & 1.359 & 1.343 & 1.375 \\
\hline & FI-7 & 0.650 & 0.003 & $59,173.472$ & 1 & 0.000 & 1.916 & 1.906 & 1.926 \\
\hline & FI-8 & 0 & & & 0 & & & & \\
\hline & $\mathrm{T}-1$ & 0.471 & 0.004 & $17,504.794$ & 1 & 0.000 & 1.602 & 1.590 & 1.613 \\
\hline & $\mathrm{T}-2$ & 0.238 & 0.004 & 4298.045 & 1 & 0.000 & 1.268 & 1.259 & 1.277 \\
\hline & $\mathrm{T}-3$ & 1.120 & 0.004 & $75,697.401$ & 1 & 0.000 & 3.065 & 3.041 & 3.090 \\
\hline & $\mathrm{T}-4$ & 1.071 & 0.004 & $59,569.100$ & 1 & 0.000 & 2.917 & 2.892 & 2.942 \\
\hline & $\mathrm{T}-5$ & 0.663 & 0.005 & $194,40.892$ & 1 & 0.000 & 1.940 & 1.922 & 1.959 \\
\hline & T-6 & 1.433 & 0.006 & $57,140.616$ & 1 & 0.000 & 4.189 & 4.140 & 4.239 \\
\hline & $\mathrm{T}-7$ & -0.419 & 0.004 & $12,046.329$ & 1 & 0.000 & 0.658 & 0.653 & 0.663 \\
\hline & $\mathrm{T}-8$ & 0 & & & 0 & & & & \\
\hline & IR-1 & 0.290 & 0.001 & $42,090.651$ & 1 & 0.000 & 1.337 & 1.333 & 1.340 \\
\hline & IR-2 & -0.002 & 0.002 & 0.679 & 1 & 0.410 & 0.998 & 0.994 & 1.003 \\
\hline & IR-3 & 0.544 & 0.002 & $51,720.404$ & 1 & 0.000 & 1.723 & 1.715 & 1.731 \\
\hline & IR-4 & 0.363 & 0.004 & 8658.865 & 1 & 0.000 & 1.438 & 1.427 & 1.449 \\
\hline & IR-5 & 1.102 & 0.004 & $87,384.162$ & 1 & 0.000 & 3.009 & 2.987 & 3.031 \\
\hline & IR-6 & 0.368 & 0.003 & $11,236.580$ & 1 & 0.000 & 1.445 & 1.435 & 1.455 \\
\hline & IR-7 & 0.147 & 0.003 & 2234.262 & 1 & 0.000 & 1.158 & 1.151 & 1.166 \\
\hline & IR-8 & 0 & & & 0 & & & & \\
\hline
\end{tabular}




\section{Continued}

\begin{tabular}{|c|c|c|c|c|c|c|c|c|c|}
\hline \multirow[t]{33}{*}{$\mathrm{C}-2$} & Intercept & -0.211 & 0.005 & 1521.768 & 1 & 0.000 & & & \\
\hline & A-1 & -0.222 & 0.004 & 3346.568 & 1 & 0.000 & 0.801 & 0.795 & 0.807 \\
\hline & A-2 & -0.370 & 0.004 & 9313.803 & 1 & 0.000 & 0.691 & 0.685 & 0.696 \\
\hline & A-3 & -0.351 & 0.004 & 6212.264 & 1 & 0.000 & 0.704 & 0.698 & 0.710 \\
\hline & A-4 & -0.571 & 0.006 & $10,648.635$ & 1 & 0.000 & 0.565 & 0.559 & 0.571 \\
\hline & A-5 & -0.048 & 0.008 & 39.275 & 1 & 0.000 & 0.953 & 0.939 & 0.967 \\
\hline & A- 6 & -0.663 & 0.007 & 9488.174 & 1 & 0.000 & 0.515 & 0.509 & 0.522 \\
\hline & A-7 & -0.780 & 0.006 & $17,165.182$ & 1 & 0.000 & 0.458 & 0.453 & 0.464 \\
\hline & A- 8 & 0 & & & 0 & & & & \\
\hline & FI-1 & -0.144 & 0.002 & 3375.551 & 1 & 0.000 & 0.866 & 0.862 & 0.870 \\
\hline & FI-2 & -0.135 & 0.002 & 4285.556 & 1 & 0.000 & 0.874 & 0.870 & 0.877 \\
\hline & FI-3 & 0.136 & 0.002 & 3254.513 & 1 & 0.000 & 1.145 & 1.140 & 1.151 \\
\hline & FI-4 & 0.125 & 0.002 & 2642.415 & 1 & 0.000 & 1.133 & 1.127 & 1.138 \\
\hline & FI-5 & -0.349 & 0.003 & $13,077.329$ & 1 & 0.000 & 0.705 & 0.701 & 0.709 \\
\hline & FI-6 & -1.608 & 0.011 & $21,990.288$ & 1 & 0.000 & 0.200 & 0.196 & 0.205 \\
\hline & FI-7 & 0.243 & 0.003 & 7396.016 & 1 & 0.000 & 1.275 & 1.268 & 1.282 \\
\hline & FI-8 & 0 & & & 0 & & & & \\
\hline & $\mathrm{T}-1$ & 0.272 & 0.004 & 5623.861 & 1 & 0.000 & 1.312 & 1.303 & 1.321 \\
\hline & $\mathrm{T}-2$ & 0.198 & 0.004 & 2907.096 & 1 & 0.000 & 1.219 & 1.210 & 1.228 \\
\hline & $\mathrm{T}-3$ & 0.529 & 0.004 & $15,444.879$ & 1 & 0.000 & 1.697 & 1.683 & 1.711 \\
\hline & $\mathrm{T}-4$ & 0.680 & 0.005 & $22,101.973$ & 1 & 0.000 & 1.973 & 1.956 & 1.991 \\
\hline & $\mathrm{T}-5$ & 0.609 & 0.005 & $16,076.011$ & 1 & 0.000 & 1.838 & 1.821 & 1.855 \\
\hline & T-6 & 0.747 & 0.007 & $13,108.097$ & 1 & 0.000 & 2.111 & 2.084 & 2.138 \\
\hline & $\mathrm{T}-7$ & -0.452 & 0.004 & $13,438.499$ & 1 & 0.000 & 0.636 & 0.632 & 0.641 \\
\hline & $\mathrm{T}-8$ & 0 & & & 0 & & & & \\
\hline & IR-1 & 0.369 & 0.001 & $62,997.894$ & 1 & 0.000 & 1.447 & 1.443 & 1.451 \\
\hline & IR-2 & 0.046 & 0.002 & 356.299 & 1 & 0.000 & 1.047 & 1.042 & 1.052 \\
\hline & IR-3 & 0.288 & 0.003 & $12,249.371$ & 1 & 0.000 & 1.334 & 1.327 & 1.340 \\
\hline & IR-4 & 0.468 & 0.004 & $13,529.699$ & 1 & 0.000 & 1.596 & 1.584 & 1.609 \\
\hline & IR-5 & 0.521 & 0.004 & $15,213.678$ & 1 & 0.000 & 1.684 & 1.670 & 1.698 \\
\hline & IR-6 & 0.469 & 0.004 & $17,717.543$ & 1 & 0.000 & 1.598 & 1.587 & 1.609 \\
\hline & IR-7 & 0.417 & 0.003 & $18,264.884$ & 1 & 0.000 & 1.517 & 1.508 & 1.526 \\
\hline & IR-8 & 0 & & & 0 & & & & \\
\hline
\end{tabular}

The reference category is: Never had credit or code C-3.

Kenya (telecommunication company) and the Kenya Commercial Bank.

The output in Table 3 shows the parameter estimates of the multinomial logistic regression of the perceptions and behaviour of the consumers against the 
credit usage. The perceptions and behaviour are measured using source of advice, characteristics of the most important financial instruments, most trusted financial provider and the financial institutions with the highest interest rates. The credit usage is categorized as: currently have credit, used to have credit and never had credit.

\subsection{Currently Have Credit Relative to Never Had Credit}

The multinomial logit estimate for currently have credit relative to never had credit for the perceptions and behaviour of the consumers is presented based on Table 3 with the abbreviations extracted from Table 2.

\subsubsection{Source of Financial Advice}

The consumers had varied sources of financial advice. For those who sort financial advice from different sources relative to other sources, the relative risk for currently have credit to never had credit would be expected to decrease (That is, advice from self, friends/family, bank, ROSCA/chama, who did not know their source of advice and radio as a source of advice relative to other sources of advice is $0.595,0.481,0.775,0.666,0.768,0.333$ respectively). The other variables in the model are held constant (logit for self, friends/family, bank, ROSCA/chama, no known advice source and radio relative to other sources is $-0.519,-0.733$, $-0.255,-0.406,-0.264$ and -1.099 respectively). That is, consumers whose source of financial advice is from themselves, friends/family, ROSCA/ chama, bank, radio and those without any source of advice are less likely than those with other sources of advice to currently have credit relative to never had credit.

For SACCO as source of financial advice relative to other sources, the relative risk for currently have to never had credit would be expected to increase by a factor of 1.380 and the logit is 0.322 . That is, SACCO as source of advice increases the chances of currently having credit relative to never had credit. Since $(\mathrm{p}<0.001)$, the difference between these sources of financial advice and other sources of financial advice has been found to be statistically different for currently have to never had credit given the other perceptions and behaviour of the consumers in the model. Therefore, advice from SACCO increased the chances of currently have credit to never had credit while advice from self, family, friends, bank, chama and radio decreased the chances of having credit.

\subsubsection{Characteristics of Financial Instruments}

The characteristics of the financial instruments to keep most of money, easy to access and most trusted relative to other characteristics, the relative risk for currently have credit to never had credit would be expected to decrease by a factor of $0.792,0.916$ and 0.955 respectively. This given the other variables in the model being held constant (logit for keep most money, easily accessed and most trusted relative to other characteristics is $-0.233,-0.088$ and -0.046 respectively).

The characteristics of the financial instruments to help in emergencies, use most often, money to invest and safe relative to other characteristics, the relative 
risk for currently have credit to never had credit would be expected to increase by a factor of 2.173, 1.072, 1.359 and 1.916 respectively; given that the other variables in the model being held constant (logit for help in emergencies), use most often, money to invest and safe relative to other characteristics is $0.776,0.069$, 0.307 and 0.650 respectively.

Since $p<0.001$, the difference between these characteristics of financial instruments and other characteristics has been found to be statistically different for currently have to never had credit given the other perceptions and behaviour of the consumers in the model. Therefore, if an instrument keeps most of money, is easy to access money and most trusted, it reduced the chances of currently having credit relative to never had credit. If the instrument help in emergencies, used most often, offers money to invest and safe increased the chances of currently have credit relative to never had credit.

\subsubsection{Most Trusted}

The most trusted sources of finance (Microfinance, SACCO, chama, Fintech, bank and mobile money) relative to other sources, the relative risk for currently have credit to never had credit would be expected to increase by a factor of $4.189,3.065,2.917,1.940,1.602$ and 1.268 respectively; given the other variables in the model are held constant. The logit for most trusted source of finance (Microfinance, SACCO, chama, Fintech, bank and mobile money) relative to other trusted sources is $1.433,1.120,1.071,0.663,0.471$ and 0.238 respectively.

Since $(p<0.001)$, the difference between the most trusted sources of finance and other sources has been found to be statistically different for currently have to never had credit given the other perceptions and behaviour of the consumers in the model. Therefore, trust of the sources of finance increases current credit usage relative to never had credit. The most trusted is microfinance, then SACCO, Chama, Fintech (Mshwari/KCB Mpesa), bank and the least trusted is mobile money.

\subsubsection{Provider with Highest Interest Rate}

The provider with the highest interest rate (or cost of credit) relative to those who did not know who charges the highest interest rate, the relative risk for currently have credit to never had credit would be expected to increase. The respective increase are by a factor of $3.009,1.723,1.445,1.438,1.337$ and 1.158 for shylock, microfinance, Chama, informal money lenders, banks and Fintech (Mshwari/KCB Mpesa). This is given that the other variables in the model are held constant. The logit for providers with the highest interest rate for the shylock, microfinance, Chama, informal money lenders, banks and Fintech (Mshwari/KCB Mpesa) is $1.102,0.544,0.368,0.363,0.290$ and 0.147 respectively.

Since $(p<0.001)$, the difference between the provider interest rate and interest rates from other sources has been found to be statistically different for currently have to never had credit given the other perceptions and behaviour of the consumers in the model. Therefore, consumers borrow from shylock, chama, mi- 
crofinance, bank, informal lenders and Fintech even though they are aware of the high interest rates they charge.

The four variables of the study indicate that the characteristics of financial instrument and source of financial advice decrease the chances of currently having credit while trust and cost of credit increase the chances of currently having credit. Customers care less on advice sources and characteristics of the financial instrument but very keen on how much they trust the provider and the cost of credit from the providers.

\subsection{Used to Have Credit Relative to Never Had Credit}

The multinomial logit estimate for used to have credit relative to never had credit for the perceptions and behaviour of the consumers is presented based on Table 3 with the abbreviations extracted from Table 2.

\subsubsection{Source of Financial Advice}

The consumers had varied sources of financial advice. For those who sort financial advice from different sources relative to other sources, the relative risk for currently have credit to never had credit would be expected to decrease (That is, advice from self, friends/family, bank, ROSCA/chama, SACCO, unknown source of advice and radio as a source of advice relative to other sources of advice is $0.801,0.691,0.704,0.565,0.953,0.515$ and 0.458 respectively). The other variables in the model are held constant (logit for self, friends/family, bank, ROSCA/chama, no known advice source and radio relative to other sources is $-0.222,-0.370,-0.351,-0.571,-0.048,-0.663$, and -0.780 respectively). That is, consumers whose source of financial advice is self, friends/family, bank, ROSCA/chama, SACCO, unknown and radio are less likely than those with other sources of advice to have had credit relative to never had credit.

Since $(p<0.001)$, the difference between these sources of financial advice and other sources of financial advice has been found to be statistically different for used to have had credit given the other perceptions and behaviour of the consumers in the model. Therefore, irrespective of the source of advice, there is a decrease of chances of a consumer to have had credit previously.

\subsubsection{Characteristics of Financial Instruments}

The characteristics of the financial instruments to keep most of money, easy to access, use most often and provide money to invest relative to other characteristics, the relative risk for used to have credit to never had credit would be expected to decrease by a factor of $0.866,0.874,0.705$ and 0.200 respectively; given the other variables in the model being held constant (logit for keep most money, easily accessed, use most often and money to invest relative to other characteristics is $-0.144,-0.135,-0.349$ and -1.608 respectively.

The characteristics of the financial instruments to help in emergencies, most trusted and safe relative to other characteristics, the relative risk for used to have credit to never had credit would be expected to increase by a factor of $1.145,1.133$ 
and 1.275 respectively; given that the other variables in the model being held constant (logit for help in emergencies, use most often, money to invest and safe relative to other characteristics is $0.136,0.125$ and 0.243 respectively. Since $p<0.001$, the difference between these characteristics of financial instruments and other characteristics has been found to be statistically different for currently have to never had credit given the other perceptions and behaviour of the consumers in the model. Therefore, the characteristics of financial instrument that influence a customer to never have credit is ability to keep most of the money and ease of access.

\subsubsection{Most Trusted}

The most trusted sources of finance (bank, mobile money, SACCO, chama, Fintech and microfinance) relative to other sources, the relative risk for used to have credit to never had credit would be expected to increase by a factor of $1.312,1.219,1.697,1.973,1.838$ and 2.111 respectively; given the other variables in the model are held constant. The logit for most trusted source of finance (bank, mobile money, SACCO, chama, Fintech and microfinance) relative to other trusted sources is $0.272,0.198,0.529,0.680,0.609$ and 0.747 respectively.

Since $(p<0.001)$, the difference between the most trusted sources of finance and other sources has been found to be statistically different for used to have to never had credit given the other perceptions and behaviour of the consumers in the model. Therefore, trust of the sources of finance increases the chances to have ever had credit relative to never had credit. Trust is important to increase chances of credit usage.

\subsubsection{Provider with Highest Interest Rate}

The provider with the highest interest rate (or cost of credit) relative to those who did not know who charges the highest interest rate, the relative risk for used to have credit to never had credit would be expected to increase. The respective increase are by a factor of 1.447, 1.047, 1.334, 1.596, 1.684, 1.598 and 1.517 for bank, SACCO, microfinance, informal money lender, shylock, chama and Fintech (Mshwari/KCB Mpesa). This is given that the other variables in the model are held constant. The logit for providers with the highest interest rate for bank, SACCO, microfinance, informal money lenders, shylock, chama and Fintech (Mshwa$\mathrm{ri} / \mathrm{KCB}$ Mpesa) is $0.369,0.046,0.288,0.468,0.521,0.469$ and 0.417 respectively.

Since $(p<0.001)$, the difference between the provider interest rate and interest rates from other sources has been found to be statistically different for used to have to never had credit given the other perceptions and behaviour of the consumers in the model. Therefore, the cost of credit reduced the chances of a consumer to never have had credit.

\subsection{Summary}

The source of financial advice differs from currently have relative to never had credit and used to have relative to never had credit. Radio as a source of advice increase chances of never using credit and SACCO advice increases the chances 
of credit usage. The categories in the source of financial advice tend to decrease credit usage.

The characteristics of financial instruments chances of decreasing or increasing credit usage tend to change based on if the reference is current or past credit usage. The ability to keep most money and ease of access decreased chances of credit usage while helping in emergencies and safety of the money increased credit usage.

Trust of the financial institution and cost of credit relative to those not sure about trust and cost of credit increased chances of credit usage. That is, consumers aware about trust and cost of credit are better placed to use credit as opposed to those not sure about these factors.

\section{Conclusions}

The source of financial advice increased the chances of a consumer to have never taken credit. A SACCO member had an increase in the chances of currently having credit. Majority of the respondents make their own financial decisions or seek advice from friends and family members. The key characteristics of financial instruments are ease of access, to help in emergencies and trust. The odds of currently have credit to never had credit increased in the financial instrument helps during emergencies, provides money to invest, safe to use and is frequently used. A decrease in current use of credit is observed if the instrument keeps most money, easy to access and trusted. The odds of used to have credit to never had credit increased if the financial instrument helps during emergencies, the instrument is trusted and safe. If the financial instrument helps to keep money, ease of access to funds, provides money to invest and used most often decreased the odds of current to have credit to never had credit. The most trusted institutions are banks and mobile money. Trust of financial institution decreased the chances of a consumer to never have had credit. Banks are the providers with the highest cost of credit but in general, the perception on cost of credit increased the chances to have credit, both at present and in the past.

SACCOs are the most preferred mode of accessing financial services as they are more trusted, offer reliable source of financial advice and lower cost of credit as compared to other financial service providers. The change in demographics has tilted the perceptions and behaviour of consumers toward credit usage from the financial service providers. On the limitations of this paper, most of the data is qualitative, thus limiting the ability to perform other statistical analysis. Further research can analyze the relationship between credit usage and credit access from the 2016 FinAccess Household survey as this data set is rich and deep on financial usage and access, covering knowledge, perceptions, behaviour and understanding of financial services and products.

\section{Conflicts of Interest}

The authors declare no conflicts of interest regarding the publication of this paper. 


\section{References}

[1] Allen, F., Demirguc-Kunt, A., Leora, K. and Peria, M. (2016) The Foundations of Financial Inclusion: Understanding Ownership and Use of Formal Accounts. Journal of Financial Intermediation, 27, 1-30. https://doi.org/10.1016/j.jfi.2015.12.003

[2] Demirguc-Kunt, A., Klapper, L., Singer, D. and Oudheusden, P. (2015) The Global Findex Database 2014: Measuring Financial Inclusion around the World. Development Research Group Finance and Private Sector Development Team. Policy Research Working Paper 7255, The World Bank, Washington DC. https://doi.org/10.1596/1813-9450-7255

[3] Amidzic, G., Massara, A. and Miolou, A. (2014) Assessing Countries' Financial Inclusion Standing-A new Composite Index. International Monetary Fund, Washington DC, Working Paper, WP/14/36.

[4] Demirguc-Kunt, A., Klapper, L., Singer, D., Ansar, S. and Hess, J. (2017) The Global Findex Database: Measuring Financial Inclusion and the Fintech Ievolution 2017. International Bank for Reconstruction and Development/The World Bank, Washington DC. https://doi.org/10.1596/978-1-4648-1259-0

[5] International Finance Corporation (IFC) (2017) How Fintech Is Reaching the Poor in Africa and Asia: A Start-Up Perspective. International Finance Corporation, World Bank Group, Note 34, Washington DC.

[6] Borovicka, J. (2007) Banking Efficiency and Foreign Ownership in Transition: Is There Evidence of a Cream Skimming Effect? CERGE-EI Working Paper Series, Center for Economic Research and Graduate Education.

[7] International Finance Corporation (IFC) (2018) Digital Access: The Future of Financial Inclusion in Africa. International Finance Corporation, World Bank Group, Washington DC.

[8] Burke, J. and Hung, A.A. (2015) Trust and Financial Advice. RAND Corporation, Santa Monica, Working Paper Series (WR-1075). https://doi.org/10.7249/WR1075

[9] Annim, S., Arun, T. and Koslov, P. (2012) Effect of Perceptions and Behaviour on Access to and Use of Financial Service: Evidence from South Africa. IZA Discussion, Paper No. 7042.

[10] Linciano, N., Gentile, M., Lucarelli, C. and Soccorso, P. (2015) Financial Disclosure, Risk Perception and Investment Choices: Evidence from a Consumer Testing Exercise. CONSOB Working Paper 82. https://doi.org/10.2139/ssrn.2616277

[11] Price Water House Cooper (PWC) (2016) DeNovo Q2 2016 FinTech Recap and Funding Review and the Un(der) Banked Is Fintech's Largest Opportunity. DeNovo: A Platform to Understand How Disruption Impacts Business Strategy and What Actions to Take.

[12] Financial Sector Deepening (FSD) (2010) Financial Capability and the Poor: Are We Missing the Mark? Bankable Frontier Associates, Issue 2, Nairobi.

[13] Financial Sector Deepening (FSD) (2016) 2016 FinAccess Household Survey. Collaboration between Financial Sector Deepening. Kenya National Bureau of Statistics and Central Bank of Kenya Report, Nairobi.

[14] Financial Sector Deepening (FSD) (2014) A Buck Short: What Financial Diaries Tell Us about Building Financial Services That Matter to Low Income Women. Report by Bankable Frontier Associates, Nairobi.

[15] Ntwiga, D.B., Ogutu, C. and Kirumbu, M.K. (2018) Inclusion of Peer Group and Individual Low-Income Earners in M-Shwari Micro-Credit Lending: A Hidden Markov Model Approach. International Journal of Electronic Finance, 9, 121-133. 
https://doi.org/10.1504/IJEF.2018.092195

[16] Kranz, N.C. (2005) Indicators of Financial Access: Household-Level Survey. The World Bank, Financial Sector Vice-Presidency. Conference on Measuring Access, Washington DC, October 2004.

http://documents.worldbank.org/curated/en/390821468158076107/Indicators-of-fin ancial-access-household-level-surveys

[17] Ntwiga, D.B. (2017) Credit Risk Analysis for Low Income Earners. Proceedings of the 6 th Annual Kenya Bankers Association Banking Research Conference, Nairobi, September 2017, 1-32.

[18] Djankov, S., Miranda, P., Seria, E. and Sharma, S. (2008) Who Are the Unbanked? Policy Research Working Paper 4647, World Bank, Washington DC. https://doi.org/10.1596/1813-9450-4647

[19] Agaliotis, K. and Hadzic, M. (2015) Predicting Retail Banking Consumer Behaviour Using Statistics. The European Journal of Applied Economics, 12, 43-51. https://doi.org/10.5937/ejae12-7916

[20] Beckett, A., Hewer, P. and Howcroft, B. (2000) An Exposition of Consumer Behaviour in the Financial Services Industry. International Journal of Bank Marketing, 18, 15-26. https://doi.org/10.1108/02652320010315325

[21] Diacon, S. and Ennew, C. (2001) Consumer Perceptions of Financial Risk. The Geneva Papers on Risk and Insurance, 26, 389-409. https://doi.org/10.1111/1468-0440.00125

[22] Ntwiga, D.B. (2016) Social Network Analysis for Credit Risk Modeling. Unpublished PhD Thesis, School of Mathematics, University of Nairobi, Nairobi.

[23] Ntwiga, D.B., Ogutu, C., Kirumbu, M.K. and Weke, P. (2018) A Hidden Markov Model of Risk Classification among the Low Income Earners. Journal of Finance and Economics, 6, 242-249. https://doi.org/10.12691/jfe-6-6-6

[24] Davis, F.D. (1989) Perceived Usefulness, Perceived Ease of Use, and User Acceptance of Information Technology. MIS Quarterly, 13, 319-340. https://doi.org/10.2307/249008

[25] Chen, S., Li., S. and Li, C. (2011) Recent Related Research in Technology Acceptance Model: A Literature Review. Australian Journal of Business and Management Research, 1, 124-127.

[26] Lai, P.C. (2017) The Literature Review of Technology Adoption Model and Theories for the Novelty Technology. Journal of Information Systems and Technology Management, 14, 21-38. https://doi.org/10.4301/S1807-17752017000100002 